\title{
EVALUATION OF AN ALTERNATIVE FOR MANUFACTURE OF ARTISANAL MINAS CHEESE FROM MICRO-REGION OF CAMPO DAS VERTENTES, USING PASTEURIZED MILK AND INDUSTRIAL DAIRY CULTURES
}

\section{Avaliação de uma alternativa para a fabricação de queijo Minas artesanal da micro-região do Campo das Vertentes, utilizando leite pasteurizado e culturas lácteas industriais}

\section{Luiz Carlos Gonçalves Costa Júnior ${ }^{*}$, Lorena Evangelista Fernandes ${ }^{2}$, Renata Golin Bueno} Costa $^{I}$, Fernando Antônio Resplande Magalhães ${ }^{l}$, Junio César Jacinto de Paula ${ }^{l}$, Denise Sobral ${ }^{1}$

\begin{abstract}
The study aimed to evaluate an alternative for the manufacture of artisanal Minas cheese, using pasteurized milk and industrial dairy cultures. The cheeses were ripened for 60 days, and both presented no differences in texture profile. The enumeration of coliforms $\left(30^{\circ} \mathrm{C}\right.$ and $\left.45^{\circ} \mathrm{C}\right)$, Staphylococcus aureus, Listeria spp., and Salmonella spp. were below the limits of the legislation, for both treatments. The physicochemical characteristics, including sodium chloride, moisture, and ash levels did not differ between the treatments, while significant differences were observed for water activity, fat, $\mathrm{pH}$, protein, and proteolysis indexes of the cheeses, throughout the ripening period. The sensory attributes such as texture, salty taste, and odor did not differ between treatments; however, the overall impression was better evaluated in the artisan cheeses at 40 days. Higher acceptance scores were observed for the attributes consistency, aroma, and flavor at the end of ripening, while the aftertaste was observed in artisanal cheeses after 20 days of ripening. The acceptance test was similar for both cheeses. The technology evaluated in this study may be an effective alternative for the manufacture of artisanal Minas cheese from Campo das Vertentes.

Keywords: ripening; texture profile; Brazilian cheese; raw milk; microbiology.

1 Empresa de Pesquisa Agropecuária de Minas Gerais, Instituto de Laticínios Cândido Tostes, Rua Tenente Luiz de Freitas, 116, Santa Terezinha, 36045-560, Juiz de Fora, MG, Brasil. E-mail: luizcarlos@ epamig.br

2 Universidade Federal de Juiz de Fora, Faculdade de Farmácia, Mestrado Profissional em Ciência e Tecnologia do Leite e Derivados (discente), Juiz de Fora, MG, Brasil.

* Autor para correspondência
\end{abstract}

Recebido / Received: 08/04/2019

Aprovado / Approved: 30/07/2019 


\section{RESUMO}

O objetivo foi criar alternativa aos laticínios na produção de versão do queijo Minas artesanal, com leite pasteurizado e culturas lácteas industriais. Como referência, foi identificada uma queijaria artesanal, além de uma unidade industrial, ambas na região Campo das Vertentes. Os queijos produzidos nas duas tecnologias foram maturados por 60 dias, sendo que ambos não apresentaram diferenças quanto ao perfil de textura. Contagens de coliformes $\left(30^{\circ} \mathrm{C}\right.$ e $\left.45^{\circ} \mathrm{C}\right)$, Staphylococcus aureus, Listeria spp. e Salmonella spp., aos 2 e 60 dias, apresentaram-se abaixo dos limites da legislação, em ambos tratamentos. Aspectos físico-químicos como teores de cloreto de sódio, umidade e cinzas não diferiram entre tecnologias, e atividade de água, gordura, $\mathrm{pH}$, proteína total, e índices de proteólise apresentaram-se diferentes em períodos pontuais entre queijos. Atributos sensoriais como textura, gosto salgado e odor não diferiram entre tratamentos, já aspecto global, foi mais bem avaliado nos queijos artesanais aos 40 dias. Consistência, aroma e sabor obtiveram notas mais altas no fim da maturação, e, cor interna e sabor residual, foram mais bem avaliados após 20 dias nos artesanais. A intenção de compra e aceitação foram as mesmas. A tecnologia desenvolvida é alternativa possível para produção em laticínios do queijo Minas artesanal do Campo das Vertentes.

Palavras-chave: maturação; perfil de textura; físico-química; análise sensorial; microbiologia.

\section{INTRODUCTION}

There is a great variety of cheese that reflects the Brazilian culture. The cheese manufacture in the state of Minas Gerais stands out in the national scenario, and a large part is artisanal production, using raw milk collected on the property itself, in small family farms (MINAS GERAIS, 2012).

Minas Gerais is the Brazilian state that produces the most milk, on average, 9.5 billion liters in 2015, from small and medium-sized properties, of which 6.1 billion are processed into cheese every year (IBGE, 2017).

Although the micro-region Campo das Vertentes is historically a cheese producer, there are few studies in the area, without studies on the manufacture of artisanal cheese at an industrial level, which may be extremely important for the dairy industry. The microregion Campos das Vertentes occupies an area of about $6,254 \mathrm{~km}^{2}$ encompassing 15 municipalities (EMATER, 2017), and has a great demand for the production of artisanal Minas cheese in an industrial scale, as occurring in European countries like Portugal, Italy, and France. Therefore, this study aimed to evaluate an alternative to produce cheese with the characteristics similar to the products found in the local market of the micro-region Campo das Vertentes, with greater food safety, using pasteurized milk and industrial dairy cultures.

\section{MATERIAL AND METHODS}

\section{Cheese manufacture}

The study was performed in a dairy industry located in Campo das Vertentes, which have met the project's premises, inspected by the Inspection Service, with a quality control laboratory that can allow characterization of the raw material and decision making. A traditional artisanal Minas cheese processing industry, located in the 
same region, in the city of Tiradentes was also selected.

Preliminary tests were carried out to adapt the dairy processing technology, aiming to obtain the sensory characteristics similar to those present in the traditional cheese from the micro-region Campo das Vertentes. The cheeses were made in 4 replicates on different days. Cheeses made with pasteurized milk (industrial sample) and raw milk (artisanal sample) were manufactured according to Figure 1.

\section{Physicochemical characterization}

Milk was characterized for titratable acidity and fat content, and cheese was evaluated at 2, 20, 40, and 60 days of ripening for water activity (aw), $\mathrm{pH}$, moisture, protein, fat, ash, $\mathrm{NaCl}$ (BRASIL, 2006), and extension and depth of proteolysis indexes using the following equations:

Extent of proteolysis $=(\% \mathrm{pH} 4.6$-soluble nitrogen $/ \%$ total nitrogen) $\mathrm{x} 100$

Depth of Proteolysis $=(\% 12 \%$ TCAsoluble nitrogen $/ \%$ total nitrogen) $\mathrm{x} 100$

The $\mathrm{pH} 4.6$-soluble nitrogen and $12 \%$ TCA-soluble nitrogen were determined according to Barbano et al. (1991), and AOAC (CUNNIFF, 1995), respectively.

\section{Microbiological characterization}

Microbiological characterization was performed at 2 and 60 days of ripening to determine the presence or absence of Listeria spp. and Salmonella spp. (BRASIL, 2003) and to enumerate the coliforms and Staphylococcus aureus (LATIMER JUNIOR, 2016) to ensure the quality of the cheese and compliance with the current legislation.

\section{Texture profile analysis}

The texture profile (TPA) of the cheeses was determined at 2, 20, 40, and 60 days by a double compression test using acrylic TA-2 probe (Texture Technologies Corp. and Stable Micro Systems, Hamilton, MA), $30 \mathrm{~mm}$ in diameter and $36 \mathrm{~mm}$ width, in a CT3 Texture Analyzer (Brookfield AMETEK, Middleboro, MA, USA). Data were collected through the "Texture Pro CT" program (Brookfield AMETEK, Middleboro, MA, USA). For the test, cheese without rind was cut into cubes of $20 \mathrm{~mm}$ of edge, and the texture determined in six replicates at $10^{\circ} \mathrm{C}$. During the tests, the samples were compressed at $30 \%$, test speed $1 \mathrm{~mm} / \mathrm{s}$ and load cell 4,500 g.

\section{Sensory evaluation}

Quantitative descriptive analysis (QDA) (STONE et al., 2012) of cheeses was performed at 20, 40, and 60 days in individual booths of the sensory evaluation laboratory at EPAMIG ILCT, with seven trained assessors. The acceptance test (hedonic scale of 9 points) (MEILGAARD et al., 2007) was performed in the region of Campo das Vertentes, with 30 assessors / treatment / repetition / time, with a total of 720 determinations, and the samples were presented coded in monodic form.

For the QDA, researchers and students were selected at EPAMIG ILCT, aged from 28 to 60 years, 4 male and 3 female, who had previous experience in the sensory evaluation of dairy products. The assessors defined 8 descriptors by consensus during the terminology development phase (Table 1). Subsequently, the participants participated in the training sessions (four two-hour sessions), which consisted of evaluating the artisanal cheese using the descriptive terms to describe and quantify the attributes in a $150 \mathrm{~mm}$ unstructured line scale, anchored at the ends. This procedure was repeated until a consensus was reached. Then, each sample was served in a monadic form, and unsalted biscuits and drinking water were supplied 
Pasteurization: Heating $75^{\circ} \mathrm{C} / 15 \mathrm{~s}$ and cooling to $32^{\circ} \mathrm{C}$

Addition of calcium chloride $(20 \mathrm{~g} / 100 \mathrm{~L})$

Addition of starter culture: Streptococcus thermophilus, Lactobacillus delbrueckii subsp. bulgaricus e Lactobacillus helveticus subsp. helveticus $(10 \mathrm{U} / 2000 \mathrm{~L})$

Pré-ripening for $10 \mathrm{~min}$

Addition of coagulant: microbial coagulant obtained from fermentation of Rhyzomucor miehei (Lacto-Lab) $(40 \mathrm{ml} / 1000 \mathrm{~L})$. Coagulation for $40 \mathrm{~min}$

Cutting the curds into pieces of 1 a $1,5 \mathrm{~cm}$ thick

Agitation for $10 \mathrm{~min}$

Whey removal and addition of water at $70^{\circ} \mathrm{C}$

Agitation of curd for 15 min

Placing the curd in perforated moulds $1 \mathrm{~kg}$, with 13 to $15 \mathrm{~cm}$ in diameter. Manual pressing: 5 min in the mold

Dry salt: Salt to cover up the surface $/ 30 \mathrm{~min}$. Turn and salt on the opposite surface

Storage at room temperature for 3 days

Storage for 10 days at $21^{\circ} \mathrm{C}$ without mold

Storage for 3 days at cold chamber $\left(10^{\circ} \mathrm{C}\right)$

Storage for 10 days at room temperature
Raw milk: obtained immediately after milking, filtering on clean and disinfected cloth and then placed in the production tank

Addition of industrial bovine cogulant (manufacturer's instructions)

Addition of endogenous starter cultures ("pingo") : $1 \%$ of the volum of milk

\section{Resting}

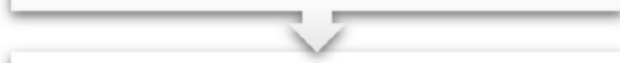

Cutting the coagulum after $\mathbf{3 5}$ min

Agitation

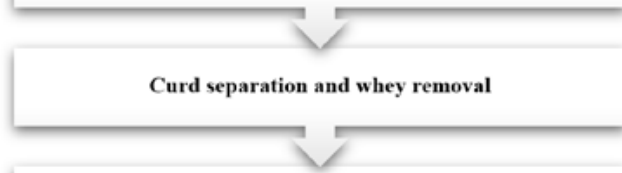

Placing the curd in plastic molds (13 a $15 \mathrm{~cm}$ in diameter)

Manual squeezing of curd and whey removal

Dry salt: Salt to cover up the surface $/ 30 \mathrm{~min}$. Turn and salt on the opposite surface

Storage at room temperature for 2 days

Drying on wooden shelves with successive turns

Ripening at room temperature

Aesthetics of cheese

Figure 1 - Cheese manufacture using the industrial treatment with pasteurized milk and commercial culture, and the artisanal treatment in the micro-region Campo das Vertentes, MG, Brazil 
as a palate cleanser. At each test period, the samples were presented with random threedigit codes in individual booths.

\section{Statistical analysis}

The experiment was carried out in a split-plot design for all variables studied, considering the treatment as the main factor, and time as sub-factor, in four replications. The results were analyzed by ANOVA and mean comparison tests (Tukey's test) at a level of $5 \%$ of significance.

\section{RESULTS AND DISCUSSION}

\section{Physicochemical characterization}

The mean titratable acidity values of both the industrial and artisanal production were $0.15 \%(\mathrm{w} / \mathrm{v})$ and $0.16 \%(\mathrm{w} / \mathrm{v})$ lactic acid, respectively. The fat content of milk from the industrial and artisanal manufacturing was $3.0 \%$ and $3.7 \%(\mathrm{w} / \mathrm{v})$, respectively.

The water activity of cheese was not influenced by the treatments $(\mathrm{p}>0.05)$; however, as expected, the values decreased

Table 1 - Definition of the descriptive terms for the artisanal Minas cheese

\begin{tabular}{|c|c|c|}
\hline Attribute & Definition & Reference (extremes of the intensity scale) \\
\hline Overall impression & $\begin{array}{l}\text { Appearance of typical } \\
\text { artisanal cheese }\end{array}$ & $\begin{array}{l}\text { Typical } \\
\text { Atypical }\end{array}$ \\
\hline Consistency & $\begin{array}{l}\text { Strength needed to } \\
\text { chew the cheese }\end{array}$ & $\begin{array}{l}\text { Soft: Minas Padrão cheese } \\
\text { Hard: Parmesan cheese. }\end{array}$ \\
\hline Texture & $\begin{array}{l}\text { Appearance concerning } \\
\text { the presence of holes }\end{array}$ & $\begin{array}{l}\text { Open: with mechanical holes } \\
\text { Closed: no holes. }\end{array}$ \\
\hline Typical odor & $\begin{array}{l}\text { Associated with typical } \\
\text { Minas cheese }\end{array}$ & $\begin{array}{l}\text { Absent: absence of odor } \\
\text { Very pronounced: excessive odor. }\end{array}$ \\
\hline Aroma & $\begin{array}{l}\text { Associated with typical } \\
\text { Minas cheese }\end{array}$ & $\begin{array}{l}\text { Absent: absence of aroma } \\
\text { Very pronounced: Parmesan. }\end{array}$ \\
\hline Salty taste & $\begin{array}{l}\text { Associated with the } \\
\text { amount of salt in cheese }\end{array}$ & $\begin{array}{l}\text { Absent: Minas Frescal cheese }(1.2 \% \text { salt }) \text {. } \\
\text { Very pronounced: gorgonzola cheese }(3.5 \% \text { salt }) \text {. }\end{array}$ \\
\hline Typical flavor & $\begin{array}{l}\text { Characteristic flavor of } \\
\text { artisanal cheese. }\end{array}$ & $\begin{array}{l}\text { Little: Minas Padrão cheese } \\
\text { Strong: Parmesan cheese. }\end{array}$ \\
\hline Residual aftertaste & $\begin{array}{l}\text { Flavor that remains } \\
\text { after a certain time of } \\
\text { analysis. }\end{array}$ & $\begin{array}{l}\text { Absent: none. } \\
\text { Very pronounced: excess aftertaste, very ripened } \\
\text { cheese }\end{array}$ \\
\hline
\end{tabular}


during ripening $(\mathrm{p}<0.05)$ (Table 2$)$ after 20 days and 2 days for the artisanal and industrial cheese, respectively. This decrease was due to dehydration during ripening (temperature and relative humidity acting in the drying of cheeses and microorganisms) (BANKS, 1998), besides the proteolysis that releases amino acids from side chains with polar groups that interact with water. Similar results were found in artisanal cheeses in the micro-region of Campo das Vertentes, with an average value of $0.91 \%(\mathrm{w} / \mathrm{w})(\mathrm{COSTA}$ JÚNIOR et al., 2014).

As observed for aw, the moisture

Table 2 - Physicochemical characterization of artisanal and industrial cheeses at times 2, 20, 40 , and 60 days after manufacturing (mean (SD)), $\mathrm{n}=4$

\begin{tabular}{|c|c|c|c|c|c|}
\hline \multirow{2}{*}{$\begin{array}{l}\text { Physico-chemical } \\
\text { aspects }\end{array}$} & \multirow{2}{*}{ Treatments } & \multicolumn{4}{|c|}{ Ripening time (days) } \\
\hline & & 2 & 20 & 40 & 60 \\
\hline \multirow[t]{2}{*}{ Water activity } & Artisanal & $0.96(0.00)^{\mathrm{aA}}$ & $0.93(0.01)^{\mathrm{aA}}$ & $0.88(0.02)^{\mathrm{bA}}$ & $0.88(0.02)^{\mathrm{bA}}$ \\
\hline & Industrial & $0.96(0.00)^{\mathrm{aA}}$ & $0.89(0.03)^{\mathrm{bB}}$ & $0.88(0.02)^{\mathrm{bA}}$ & $0.88(0.02)^{\mathrm{bA}}$ \\
\hline \multirow{2}{*}{$\begin{array}{l}\text { Moisture } \\
\mathrm{g} / 100 \mathrm{~g}\end{array}$} & Artisanal & $43.41(1.09)^{\mathrm{aA}}$ & $30.78(1.51)^{\mathrm{bA}}$ & $26.70(0.77)^{\mathrm{cA}}$ & $24.04(1.26)^{\mathrm{dA}}$ \\
\hline & Industrial & $43.03(1.80)^{\mathrm{aA}}$ & $30.61(0.72)^{\mathrm{bA}}$ & $29.62(1.56)^{\mathrm{bA}}$ & $26.95(1.81)^{\mathrm{cA}}$ \\
\hline \multirow{2}{*}{$\begin{array}{l}\text { Fat } \\
\mathrm{g} / 100 \mathrm{~g}\end{array}$} & Artisanal & $32.5(1.33)^{\mathrm{cA}}$ & $38.6(2.86)^{\mathrm{bA}}$ & $42.2(0.50)^{\mathrm{aA}}$ & $40.3(2.67)^{\mathrm{abA}}$ \\
\hline & Industrial & $27.5(1.43)^{\mathrm{bB}}$ & $37.7(0.50)^{\mathrm{aA}}$ & $38.1(1.36)^{\mathrm{aB}}$ & $38.2(2.53)^{\mathrm{aA}}$ \\
\hline \multirow{2}{*}{$\begin{array}{l}\text { Protein } \\
\mathrm{g} / 100 \mathrm{~g}\end{array}$} & Artisanal & $19.70(1.35)^{\mathrm{bA}}$ & $25.97(0.48)^{\mathrm{aA}}$ & $26.92(1.27)^{\mathrm{aA}}$ & $27.26(1.09)^{\mathrm{aB}}$ \\
\hline & Industrial & $20.30(1.27)^{\mathrm{cA}}$ & $25.44(0.25)^{\mathrm{bA}}$ & $25.66(0.77)^{\mathrm{bA}}$ & $31.24(3.16)^{\mathrm{aA}}$ \\
\hline \multirow{2}{*}{$\begin{array}{l}\text { Ash } \\
\mathrm{g} / 100 \mathrm{~g}\end{array}$} & Artisanal & $3.28(0.41)^{\mathrm{bA}}$ & $3.98(0.64)^{\mathrm{abA}}$ & $4.45(0.18)^{\mathrm{aA}}$ & $4.45(0.87)^{\mathrm{aA}}$ \\
\hline & Industrial & $4.11(0.51)^{\mathrm{aA}}$ & $4.70(0.54)^{\mathrm{aA}}$ & $4.91(0.42)^{\mathrm{aA}}$ & $4.55(0.23)^{\mathrm{aA}}$ \\
\hline \multirow{2}{*}{$\begin{array}{l}\mathrm{NaCl} \\
\mathrm{g} / 100 \mathrm{~g}\end{array}$} & Artisanal & $1.1(0.22)^{\mathrm{aA}}$ & $1.2(0.09)^{\mathrm{aA}}$ & $1.5(0.22)^{\mathrm{aA}}$ & $1.2(0.03)^{\mathrm{aA}}$ \\
\hline & Industrial & $2.0(0.74)^{\mathrm{aA}}$ & $1.9(0.59)^{\mathrm{aA}}$ & $2.1(0.64)^{\mathrm{aA}}$ & $2.2(0.42)^{\mathrm{aA}}$ \\
\hline \multirow[t]{2}{*}{$\mathrm{pH}$} & Artisanal & $5.15(0.10)^{\mathrm{abA}}$ & $4.98(0.09)^{\mathrm{bA}}$ & $5.18(0.08)^{\mathrm{aA}}$ & $5.28(0.13)^{\mathrm{aA}}$ \\
\hline & Industrial & $4.93(0.07)^{\mathrm{bB}}$ & $4.91(0.15)^{\mathrm{bA}}$ & $5.06(0.08)^{\mathrm{abA}}$ & $5.22(0.10)^{\mathrm{aA}}$ \\
\hline \multirow{2}{*}{$\begin{array}{l}\text { Proteolysis } \\
\text { extension index } \\
(\%)\end{array}$} & Artisanal & $6.62(2.27)^{\mathrm{cA}}$ & $19.16(2.47)^{\mathrm{bA}}$ & $21.98(1.48)^{\mathrm{abA}}$ & $24.34(2.77)^{\mathrm{aA}}$ \\
\hline & Industrial & $5.35(0.30)^{\mathrm{bA}}$ & $12.45(1.47)^{\mathrm{aB}}$ & $14.53(2.30)^{\mathrm{aB}}$ & $12.07(2.38)^{\mathrm{aB}}$ \\
\hline \multirow{2}{*}{$\begin{array}{l}\text { Proteolysis depth } \\
\text { index }(\%)\end{array}$} & Artisanal & $2.93(1.05)^{\mathrm{bA}}$ & $15.0(2.03)^{\mathrm{aA}}$ & $18.25(2.01)^{\mathrm{aA}}$ & $16.24(7.09)^{\mathrm{aA}}$ \\
\hline & Industrial & $2.93(0.34)^{\mathrm{bA}}$ & $10.9(0.67)^{\mathrm{aA}}$ & $11.20(1.06)^{\mathrm{aB}}$ & $8.32(1.84)^{\mathrm{aB}}$ \\
\hline
\end{tabular}

a.b Means within a row (among ripening time) with different superscript lowercase letters are significantly different $(\mathrm{p}<0.05)$.

${ }^{\text {A.B }}$ Means within a column (between treatments) with different superscript uppercase letters are significantly different $(\mathrm{p}<0.05)$. 
content of the cheeses was not influenced by the treatments $(\mathrm{p}>0.05)$, with a positive correlation between aw and moisture content $\left(r^{2}=0.92\right)$. As expected, moisture decreased gradually with cheese ripening $(\mathrm{p}<0.05)$, in the artisanal treatment from the beginning to the end of ripening $(p<0.05)$, probably due to the water loss caused by the absence of packaging, thus directly affecting the moisture content. Costa Júnior et al. (2014) and Oliveira (2014) observed higher moisture contents of $35.8 \%$ and $38.1 \%(\mathrm{w} / \mathrm{w})$, respectively, in artisanal cheeses from the micro-region of Campo das Vertentes, probably due to a lower ripening period, when cheese still retains a certain amount of water.

It can be noticed that for both cheeses the moisture content is close to that expected for Minas Padrão cheese, between $46.0 \%$ and $49.0 \%(\mathrm{w} / \mathrm{w})$, reaching lower values when compared to Brazilian Parmesan at 20 days of ripening, $33.0 \%$ to $37.0 \%(\mathrm{w} / \mathrm{w})$, with a further decrease until the end of ripening (FURTADO; LOURENÇO NETO, 1994).

Differences $(p<0.05)$ were observed for the fat content between the treatments and over time. In the industrial treatment, the moisture remained stable from the 20 days of ripening, due to the controlled conditions of relative humidity and temperature, which was not observed for the artisanal cheese that depends on the natural climatic conditions. This behavior is expected during ripening, once the moisture loss can lead to an increase in the concentration of solutes in cheese.

At the beginning of ripening, the fat content of artisanal cheese was higher $(32.5 \% \mathrm{w} / \mathrm{w})$ when compared to the industrial cheese $(27.5 \% \mathrm{w} / \mathrm{w})$, once it was made using whole milk from Jersey cattle, which naturally had higher fat content. However, at the end of the ripening process, the fat contents were similar, probably due to the same moisture content at the end of ripening. The protein content of cheese also increased over the ripening time $(\mathrm{p}<0.05)$, due to the increase in the total solids of cheese.

As for the sodium chloride $(\mathrm{NaCl})$ content, there was no significant difference $(\mathrm{p}>0.05)$ between treatments and ripening time, which remained stable, despite the dry salting method, which provides a more uneven salt distribution. However, salt diffusion is related to the cheese moisture that did not differ between the treatments. This homogeneity can indicate interactions with other variables, including moisture and total dry extract, water activity and moisture, since an increase in the concentration of sodium chloride was expected due to the higher total solids content and water loss during ripening. As the artisanal cheeses were ripened without packaging and presented variations inherent in the process, some differences in size and weight were observed, which may alter the chloride content. A similar result was observed in the industrial treatment, which was also ripened without packaging for comparison purposes.

Salt plays an important role in cheese safety as it contributes to syneresis and inhibits the growth of pathogenic microorganisms due to the dehydration of the microbial cells. Thus, controlling the amount of salt on the cheese surface through the dry salting is essential for an effective ripening. Costa et al. (2004) reported that salt contents between $0.5 \%$ and $2.5 \%(\mathrm{w} / \mathrm{w})$ in cheese curd can regulate, but not inhibit the lipolysis and proteolysis processes. Costa Júnior et al. (2014) found a chloride level of $2.61 \%$ in Minas cheese produced in the micro-region of Campo das Vertentes, which is considerably higher than the values found in the present study, probably due to the differences in the manufacturing processes.

Regarding the $\mathrm{pH}$ of cheese, a difference between treatments and ripening times was observed $(\mathrm{p}<0.05)$. There was a drop in $\mathrm{pH}$ at 20 days of ripening, due to the lactose metabolism process to lactic acid by the 
action of bacteria, which increases with the increase in proteolysis due to the formation of alkaline nitrogen compounds from the protein degradation (UPADHYAY et al., 2004). This result may be due to the $\mathrm{pH}$ of the cheese from 5.0 to 5.2 after fermentation, which decreased at the beginning of ripening.

The $\mathrm{pH}$ of cheese varies according to several factors, such as type, dose, and activity of lactic cultures. In the case of cheeses made using raw milk and endogenous starter cultures (named "pingo" in Brazil), the greater oscillation in $\mathrm{pH}$ may be because cheese was not manufactured using industrialized starter cultures.

The $\mathrm{pH}$ values found in the present study are slightly higher than those found by Costa Júnior et al. (2014) in Minas cheese from the same region, with values of $5.15 \pm 0.17$, which corroborates different activities of endogenous starter cultures ("pingo") among dairies, throughout the seasonality. Concerning the industrial cheese, standardization of the dose and the type of culture used allowed lower $\mathrm{pH}$ oscillations.

The results of the analysis of variance for the extent (\% ratio of $\mathrm{NS}_{\mathrm{pH} 4.6} / \mathrm{NT}$ ) and depth of proteolysis indexes $(\%$ ratio of $\mathrm{NS}_{\text {TCA } 12 \%} / \mathrm{NT}$ ) indicate significant differences between the treatments and ripening time $(p<0.05)$. Although an increase in the extent of proteolysis index was observed in the artisanal treatment, a stabilization was observed between 40 and 60 days, probably due to the low moisture content of cheese, between $26.7 \%(\mathrm{w} / \mathrm{w})$ and $24.0 \%(\mathrm{w} / \mathrm{w})$. In the industrial treatment, an increase was observed until the 20 days of ripening, remaining constant from 20 to 60 days, together with the low moisture content.

As the extent of proteolysis index further reflects the action of the coagulant on protein hydrolysis, the raw milk and the higher enzymatic loading of endogenous starter cultures ("pingo") may have contributed to a greater activity of bacterial proteases, which can explain the greater proteolysis observed in the artisanal cheese.

The depth of proteolysis index was similar for both treatments, which increased up to 20 days of ripening, remaining constant until 60 days of the process. It is worth mentioning that the variation in depth index is related to the enzymatic nature of the lactic culture (FOX; MCSWEENEY, 1998) and the endogenous starter cultures ("pingo") used in the manufacture of artisanal cheese, which was more active in proteolysis when compared to the industrial culture, once similar moisture contents were observed in cheese throughout the ripening period.

Studies carried out in the micro-region of the Campo das Vertentes with Minas cheese during 30 days of ripening, showed an extent of proteolysis index of $12.02 \pm$ $3.55 \%(\mathrm{w} / \mathrm{w})$ and depth proteolysis index of $6.91 \pm 2.24 \%$ (COSTA JÚNIOR et al., 2014). These values are lower than those found in the present study, probably due to factors such as seasonality, milk and endogenous starter cultures ("pingo"), as well as the moisture content and other variables that contribute to the increase in proteolysis rate.

\section{Texture profile analysis (TPA)}

No significant effect of the substitution of raw milk by pasteurized milk and the manufacturing process was observed on hardness and adhesiveness of cheese $(p>0.05)$ (Table 3), which can be considered a positive result, since the texture was similar for both cheeses, with little influence of the technology adopted. However, along the ripening time, a linear increase in hardness was observed in the industrial cheese from 2 days until the end of the ripening $(\mathrm{p}<0.05)$. Although proteolysis also influences hardness, the increase during ripening is more directly related to a reduction of cheese moisture over the 60 days. The 
increase in adhesiveness during cheese ripening is acceptable $(\mathrm{p}<0.05)$, once there was an increase in fat content during ripening of cheeses without packaging, as well as in proteolysis, which provides a more adhesive texture to cheese (CHEN et al., 1979; OLSON; JOHNSON, 1990).

Cohesiveness was also not influenced by the treatments $(\mathrm{p}>0.05)$, which decreased during ripening $(\mathrm{p}<0.05)$, probably due to the moisture loss of cheeses from both treatments. Maryama et al. (2006) reported cohesiveness values inversely related to the hardness of petit-suisse cheese, as verified in this study.

The reduction in cheese elasticity at the beginning of ripening $(\mathrm{p}<0.05)$ may be due to the decrease in moisture content over time, once the cheese was extremely hard at the end of this period, which may have influenced the elastic properties, making them more brittle. However, no significant effect of the manufacturing process was observed for the cheese elasticity $(p>0.05)$.

Chewiness was not affected by both the manufacturing process and the ripening time $(p>0.05)$. Other authors reported a relationship between chewiness and hardness, with an increase in the number of chewing cycles with the increase in hardness, with a positive correlation between these factors (0.9235) (FOSTER et al., 2011). However, opposite results were observed in the present study, once the significant increase in hardness at the end of ripening was not accompanied by the increase in chewing that remained constant throughout the period evaluated.

Table 3 - Texture profile (TPA) of artisanal and industrial cheeses at times 2, 20, 40, and 60 days after manufacturing (mean (SD)), $\mathrm{n}=4$

\begin{tabular}{lccccc}
\hline \multirow{2}{*}{ Texture profile } & Treatments & \multicolumn{4}{c}{ Ripening time $($ days $)$} \\
\cline { 3 - 6 } & & 2 & 20 & 40 & 60 \\
\hline \multirow{2}{*}{ Hardness (N) } & Artisanal & $3.85(0.51)^{\mathrm{bA}}$ & $5.95(2.06)^{\mathrm{bA}}$ & $12.38(0.21)^{\mathrm{aA}}$ & $11.20(3.33)^{\mathrm{aA}}$ \\
& Industrial & $4.42(1.19)^{\mathrm{cA}}$ & $11.19(2.02)^{\mathrm{bA}}$ & $9.08(2.10)^{\mathrm{bcA}}$ & $18.75(7.03)^{\mathrm{aA}}$ \\
\multirow{2}{*}{ Adhesiveness $(\mathrm{mJ})$} & Artisanal & $0.10(0.03)^{\mathrm{bA}}$ & $0.27(0.02)^{\mathrm{bA}}$ & $0.10(0.06)^{\mathrm{aA}}$ & $0.94(0.08)^{\mathrm{aA}}$ \\
& Industrial & $0.08(0.02)^{\mathrm{cA}}$ & $0.53(0.03)^{\mathrm{cA}}$ & $0.93(0.19)^{\mathrm{abA}}$ & $1.2(0.89)^{\mathrm{aA}}$ \\
Cohesiveness & Artisanal & $0.67(0.03)^{\mathrm{aA}}$ & $0.50(0.05)^{\mathrm{bA}}$ & $0.33(0.08)^{\mathrm{cA}}$ & $0.32(0.10)^{\mathrm{cA}}$ \\
& Industrial & $0.60(0.05)^{\mathrm{aA}}$ & $0.39(0.06)^{\mathrm{bA}}$ & $0.42(0.06)^{\mathrm{bA}}$ & $0.36(0.05)^{\mathrm{bA}}$ \\
& Artisanal & $4.66(0.15)^{\mathrm{aA}}$ & $3.28(0.37)^{\mathrm{bA}}$ & $2.54(0.77)^{\mathrm{bcA}}$ & $2.06(0.55)^{\mathrm{cA}}$ \\
& Industrial & $4.43(0.18)^{\mathrm{aA}}$ & $2.85(0.66)^{\mathrm{bA}}$ & $2.77(0.23)^{\mathrm{bA}}$ & $2.53(0.46)^{\mathrm{bA}}$ \\
& Artisanal & $0.012(0.002)^{\mathrm{aA}}$ & $0.009(0.002)^{\mathrm{aA}}$ & $0.011(0.005)^{\mathrm{aA}}$ & $0.011(0.008)^{\mathrm{aA}}$ \\
Chewiness $(\mathrm{J})$ & Industrial & $0.011(0.003)^{\mathrm{aA}}$ & $0.014(0.004)^{\mathrm{aA}}$ & $0.011(0.002)^{\mathrm{aA}}$ & $0.017(0.005)^{\mathrm{aA}}$
\end{tabular}

\footnotetext{
${ }^{a . b}$ Means within a row (among ripening time) with different superscript lowercase letters are significantly different $(\mathrm{p}<0.05)$.

A.B Means within a column (between treatments) with different superscript uppercase letters are significantly different $(\mathrm{p}<0.05)$.
} 


\section{Microbiological characterization}

The coliform counts at $45{ }^{\circ} \mathrm{C}$ were within the standards established by the legislation for both treatments, once the RDC 12 (BRASIL, 2001) recommended the maximum acceptable of $5 \times 10^{3} \mathrm{CFU} / \mathrm{g}$ for medium-moisture cheese. Coliforms at $30^{\circ} \mathrm{C}$ were initially found in artisanal and industrial cheeses with $1.5 \log \mathrm{CFU} / \mathrm{g}$ at 2 days of ripening, and $1.025 \mathrm{log} \mathrm{CFU} / \mathrm{g}$ and $1.05 \mathrm{log}$ $\mathrm{CFU} / \mathrm{g}$, respectively, at 60 days. For both treatments, there was absence of coliforms at $45^{\circ} \mathrm{C}$ from 2 to 60 days of ripening.

There was no influence of the technology on the growth of Staphylococcus aureus, once no microbial counts were observed in dilutions up to $10^{-4}$. All samples showed Staphylococcus aureus counts within the standards established by the RDC $12,1 \times 10^{3} \mathrm{CFU} / \mathrm{g}$ for mediummoisture cheese. The analyses of the artisanal and industrial cheeses showed absence of Salmonella spp. and Listeria spp. in $25 \mathrm{~g}$ of sample in the times studied.

\section{Sensory evaluation}

Concerning the acceptance test (Table 4), the artisanal Minas cheese-making technology did not affect the consumers' perception $(\mathrm{p}>0.05)$. However, in relation to the ripening time, there was a significant difference $(p<0.05)$ in both tests. The artisanal cheese presented better acceptance at 20 days of ripening when compared to 60 days, while similar acceptance scores were observed for the industrial cheese during ripening. Similar scores of both treatments throughout the ripening period demonstrate that the types of Minas cheese were similar from the consumer's point of view.

No significant differences in QDA were observed for the overall appearance, texture, aroma, salty taste, odor, and flavor between the treatments $(p>0.05)$ and ripening times $(\mathrm{p}>0.05)$ (Table 5).
Regarding the overall impression, a significant increase was observed after 20 days of ripening for both treatments, with a subsequent stabilization, probably due to the ripening and the formation of cheese rind, a very particular characteristic of the artisanal cheese from the micro-region of Campo das Vertentes at 40 days.

Regarding the parameter texture, a significant difference was observed only in the first 20 days in artisanal cheese $(\mathrm{p}>0.05)$. From the 40 days, higher scores were observed, indicating a more typical aspect, which is consistent with the period in which the Minas cheese is very consumed. The manufacturing process did not affect the consumers' opinion about texture, which is considered an important factor of food acceptability and a favorable result, once a product similar to the traditional cheese is desired, with some mechanical holes, typical of manually pressed cheese.

The attribute flavor was different between treatments $(\mathrm{p}<0.05)$ only at 60 days of ripening, when the artisanal cheeses were better evaluated by the assessors. Over time, significant differences were observed only for the artisanal cheese, with higher scores from 20 to 40 days, which remained until the end of ripening. This increase may be due to the action of natural milk lipases that release free and volatile fatty acids, contributing to the cheese aroma. Although aroma is a characteristic that accentuates with time due to the proteolysis and lipolysis rates, the results indicated certain stability in the artisanal cheese from 40 to 60 days of ripening, which was observed from the beginning for the industrial cheeses.

The salty taste of cheese was not influenced by the treatments, which indicates that the efficacy of the type of salting process was similar for both the artisanal and industrial processes. In addition, the chloride content did not differ between the treatments and the ripening time, even with 
Table 4 - Acceptance scores for the artisanal and industrial cheeses at 20, 40, and 60 days of ripening (mean $(\mathrm{SD})), \mathrm{n}=4$

\begin{tabular}{cccc}
\hline \multirow{2}{*}{ Treatments } & \multicolumn{3}{c}{ Ripening time (days) } \\
\cline { 2 - 4 } & 20 & 40 & 60 \\
\hline Artisanal & $8.35(0.83)^{\mathrm{aA}}$ & $7.98(1.21)^{\mathrm{bA}}$ & $7.86(1.60)^{\mathrm{bA}}$ \\
Industrial & $7.89(0.99)^{\mathrm{aA}}$ & $8.00(0.94)^{\mathrm{aA}}$ & $8.09(1.40)^{\mathrm{aA}}$ \\
\hline
\end{tabular}

${ }^{\text {a.b }}$ Means within a row (among ripening time) with different superscript lowercase letters are significantly different $(\mathrm{p}<0.05)$.

${ }^{\text {A.B }}$ Means within a column (between treatments) with different superscript uppercase letters are significantly different $(\mathrm{p}<0.05)$.

Table 5 - Sensory attributes of the quantitative descriptive analysis (QDA) for the artisanal and industrial cheeses at 20, 40, and 60 days of ripening (mean (SD)), $\mathrm{n}=4$

\begin{tabular}{lcccc}
\hline \multirow{2}{*}{ Sensory Attributes } & Treatments & \multicolumn{3}{c}{ Ripening time (days) } \\
\cline { 3 - 5 } Overall aspect & Artisanal & $9.82(1.56)^{\mathrm{bA}}$ & $12.42(1.30)^{\mathrm{aA}}$ & $11.53(1.96)^{\mathrm{aA}}$ \\
& Industrial & $9.53(2.25)^{\mathrm{bA}}$ & $10.81(1.62)^{\mathrm{aB}}$ & $10.06(2.53)^{\mathrm{abA}}$ \\
Consistency & Artisanal & $7.96(2.86)^{\mathrm{cA}}$ & $10.15(2.36)^{\mathrm{bA}}$ & $12.32(1.28)^{\mathrm{aA}}$ \\
& Industrial & $6.85(3.23)^{\mathrm{bA}}$ & $10.09(1.93)^{\mathrm{aA}}$ & $10.68(1.53)^{\mathrm{aB}}$ \\
Texture & Artisanal & $4.23(2.66)^{\mathrm{bA}}$ & $6.47(3.35)^{\mathrm{aA}}$ & $5.92(3.36)^{\mathrm{abA}}$ \\
& Industrial & $7.74(3.93)^{\mathrm{aA}}$ & $8.70(3.38)^{\mathrm{aA}}$ & $9.57(2.99)^{\mathrm{aA}}$ \\
Odor & Artisanal & $8.06(2.09)^{\mathrm{bA}}$ & $10.16(1.47)^{\mathrm{aA}}$ & $10.08(1.37)^{\mathrm{aA}}$ \\
& Industrial & $7.74(2.22)^{\mathrm{aA}}$ & $8.90(1.86)^{\mathrm{aA}}$ & $8.57(2.35)^{\mathrm{aA}}$ \\
Aroma & Artisanal & $8.48(1.87)^{\mathrm{bA}}$ & $10.32(1.66)^{\mathrm{aA}}$ & $11.17(1.83)^{\mathrm{aA}}$ \\
& Industrial & $8.16(2.22)^{\mathrm{aA}}$ & $8.70(2.14)^{\mathrm{aA}}$ & $9.18(2.57)^{\mathrm{aB}}$ \\
Salty taste & Artisanal & $6.96(1.57)^{\mathrm{aA}}$ & $8.96(2.32)^{\mathrm{aA}}$ & $10.56(2.21)^{\mathrm{aA}}$ \\
& Industrial & $7.77(2.35)^{\mathrm{aA}}$ & $9.27(2.04)^{\mathrm{aA}}$ & $8.70(2.17)^{\mathrm{aA}}$ \\
& Artisanal & $8.35(1.65)^{\mathrm{cA}}$ & $10.51(2.00)^{\mathrm{bA}}$ & $11.89(1.77)^{\mathrm{aA}}$ \\
Flavor & Industrial & $7.87(2.71)^{\mathrm{bA}}$ & $9.75(2.12)^{\mathrm{aA}}$ & $9.87(2.03)^{\mathrm{aB}}$ \\
& Artisanal & $7.43(1.85)^{\mathrm{cA}}$ & $10.47(2.07)^{\mathrm{bA}}$ & $12.08(2.07)^{\mathrm{aA}}$ \\
& Industrial & $7.71(2.38)^{\mathrm{bA}}$ & $8.65(2.31)^{\mathrm{abB}}$ & $9.58(2.02)^{\mathrm{aB}}$ \\
\hline
\end{tabular}

a.b $\overline{\text { Means within a row (among ripening time) with different superscript lowercase letters are significantly different }}$ $(\mathrm{p}<0.05)$.

${ }^{\text {A.B }}$ Means within a column (between treatments) with different superscript uppercase letters are significantly different $(\mathrm{p}<0.05)$. 
a proportional increase in the total solids during ripening.

The flavor of the industrial cheese was not affected $(p>0.05)$ by the use of pasteurized milk and mixed cultures, when compared to the artisanal cheese, until 40 days of ripening, but a lower score was observed at 60 days, probably due to the effect of the natural lipase of the untreated milk and the greater complexity of the endogenous starter cultures ("pingo") used in the manufacture, responsible for the proteolytic and lipolytic activity of different microorganisms, which contributes to the release of precursors (amino acids, fatty acids, and esters), leading to the formation of a more pronounced flavor, even if imperceptible to untrained assessors.

For consistency, there was a significant difference between treatments $(p<0.05)$, with no significant difference for the storage time $(p>0.05)$. The artisanal cheese was harder only at 60 days ripening when compared to the industrial cheese. As observed for the internal color, cheese consistency may have increased due to the moisture loss and consequent concentration of components such as fat, resulting in a more adequate consistency for the ripened Minas Padrão cheese. In contrast, the consistency values of the industrial cheese stabilized at 40 days of ripening.

The aftertaste increased $(\mathrm{p}<0.05)$ over time within the treatments, which was continuous in the artisanal cheese, and stabilized in the industrial cheeses at 40 days of ripening. The greater perception of the aftertaste by the assessors in the artisanal cheese after 40 days may be due to the acidic and bitter components formed as a byproduct of the activity of endogenous starter cultures ("pingo") or the spoilage microbiota present in the samples. In addition, at 60 days, the same trend is observed for the artisanal cheese, which had a higher score than the industrial cheese.

The results of ADQ indicated that, at 60 days of ripening, the artisanal cheese was generally better accepted when compared to the industrial cheese. However, cheese is no longer marketed at this stage of ripening, once consumers are not in the habit of consuming the ripened product due to the loss of the typical characteristics.

\section{CONCLUSIONS}

The manufacturing technology of the artisanal and industrial Minas cheese of the micro-region of Campo das Vertentes did not alter the physicochemical characteristics of cheese, including aw, $\mathrm{pH}$, sodium chloride, moisture, and ash levels. However, moisture and aw decreased during the ripening period. There was an increase in the extent and depth of proteolysis during ripening, with higher intensity in the artisanal cheese. Although no changes were observed in the texture profile, an increase in the texture parameters was observed during ripening, except for the attribute chewiness. There was no difference in the microbial counts among the treatments. Although the consumers' acceptance was similar for both technologies, a difference was observed by the trained assessors only at the end of ripening when consumption of this product is no longer common. The technology investigated in the present study may be an effective alternative for the manufacture of artisanal Minas Padrão cheese from Campo das Vertentes.

\section{ACKNOWLEDGEMENTS}

The authors are grateful to Minas Gerais Research Support Foundation (FAPEMIG) for scholarship awarded and funding the research (APQ-03699-14).

\section{REFERENCES}

BANKS, J. M. Cheese. In: EARLY, R. (ed.). The Technology of Dairy Products. London: Springer US, 1998. p. 81-122. 
BARBANO, D. M.; LYNCH, J.; FLEMING, J. R. Direct and indirect determination of true protein content of milk by Kjeldahl analysis: collaborative study. Journal of AOAC International, v. 74, p. 281-288, 1991.

BRASIL. Ministério da Agricultura, Pecuária e Abastecimento. Secretaria de Defesa Agropecuária. Instrução Normativa $n^{\circ}$ 68, de 12 de dezembro de 2006. Oficializa os Métodos Analíticos Oficiais Físico-Químicos, para Controle de Leite e Produtos Lácteos. Diário Oficial da União: seção 1, Brasília, DF, n. 239, p. 8, 14 dez. 2006.

BRASIL. Ministério da Saúde. Agência Nacional de Vigilância Sanitária. Resolução RDC n ${ }^{\circ} 12$, de 02 de janeiro de 2001. Aprova o Regulamento Técnico sobre Padrões Microbiológicos para Alimentos. Diário Oficial da União: seção 1, Brasília, DF, n. 7, p. 45, 10 jan. 2001 .

BRASIL. Ministério da Agricultura, Pecuária e Abastecimento. Instrução Normativa $n^{\circ}$ 62 , de 26 de agosto de 2003. Oficializa os Métodos Analíticos Oficiais para Análises Microbiológicas para Controle de Produtos de Origem Animal e Água. Diário Oficial da União: seção 1, Brasília, DF, n. 181, p. 14, 18 set. 2003.

CHEN, A. H. et al. Textural analysis of cheese. Journal of Dairy Science, v. 62, p. 901-907, 1979.

COSTA JÚNIOR, L. C. G. et al. Maturação do queijo artesanal da microrregião Campo das Vertentes e os efeitos dos períodos seco e chuvoso. Revista do Instituto de Laticínios Cândido Tostes, v. 69, p. 111-120, 2014.

COSTA, R. G. B. et al. Salga de queijos em salmoura: uma revisão. Revista do Instituto de Laticínios Cândido Tostes, v. 59, p. 4149, 2004.
CUNNIFF, P. A. (ed.). Official Methods of Analysis of AOAC International. 16th ed. Arlington: AOAC International, 1995.

EMATER. Empresa de Assistência Técnica e Extensão Rural do Estado de Minas Gerais. Programa Queijo Minas Artesanal. Belo Horizonte, 2017. Disponível em: http://www. emater.mg.gov.br/portal.cgi?flagweb $=$ site tpl_queijo\&id=3299

FOSTER, K. D. et al. The Role of oral processing in dynamic sensory perception. Journal of Food Science, v. 76, n. 2, 2011.

FOX, P. F.; McSWEENEY, P. L. H. Dairy Chemistry and Biochemistry. 1th ed. Cork: International Thomson Publishing, 1998.

FURTADO, M. M.; LOURENÇO NETO, J. P. Tecnologia de queijos: manual técnico para a produção industrial de queijos. São Paulo: Dipemar, 1994.

IBGE. Instituto Brasileiro de Geografia e Estatística. Censo Agropecuário. Disponível em: http://www.sidra.ibge.gov.br Acesso em: 17 mar. 2017.

LATIMER JUNIOR, G. W. (ed.). Official methods of analysis of AOAC International. 20th ed. Gaithersburg: AOAC International, 2016.

MARYAMA, L. Y. et al. Textura instrumental de queijo petit-suisse potencialmente probiótico: Influência de diferentes combinações de gomas. Ciência e Tecnologia de Alimentos, v. 26, p. 386-393, 2006.

MEILGAARD, M. C; CIVILLE, G. V.; CARR, B. T. Sensory Evaluation Techniques. 4 th ed. Boca Raton: Taylor \& Francis, 2007. 448 p.

MINAS GERAIS. Lei $\mathrm{n}^{\circ} 20.549$, de 18 de dezembro de 2012. Dispõe sobre a produção 
e a comercialização dos queijos artesanais de Minas Gerais. Diário do Executivo do Estado de Minas Gerais: caderno 1, Belo Horizonte, MG, n. 236, p. 1, 19 dez. 2012.

OLIVEIRA, L. G. Caracterização microbiológica e físico-química durante a maturação em diferentes épocas do ano de queijo minas artesanal de produtores cadastrados da mesorregião de Campo das Vertentes - MG. 2014. Dissertação (Mestrado em Ciência Animal) - Universidade Federal de Minas Gerais, Belo Horizonte, 2014.
OLSON, N. F.; JOHNSON, M. E. Light cheese products: characteristics and economic. Food Technology, v. 44, p. 93-96, 1990.

STONE, H.; BLEIBAUM, R.; THOMAS, H. Sensory Evaluation Practices. London: Academic press, 2012.

UPADHYAY, V. K. et al. Proteolysis in cheese during ripening. In: FOX, P. F. et al. (ed.). Cheese: Chemistry, Physics and Microbiology. 3rd ed. London: Elsevier, 2004. p. 391-434. 